\title{
Gambaran Status Sosioekonomi Orangtua Murid Usia 5-12 Tahun di SD Pertiwi Kecamatan Bandung Wetan yang Mengalami Gizi Kurang
}

\author{
Fildza Khadijah, ${ }^{1}$ Franseda, ${ }^{2}$ Samsudin Surialaga ${ }^{3}$ \\ ${ }^{1}$ Program Studi Pendidikan Dokter, Fakultas Kedokteran, Universitas Islam Bandung \\ ${ }^{2}$ Departmen Biokimia, Fakultas Kedokteran, Universitas Islam Bandung \\ ${ }^{3}$ RSUD Kesehatan Kerja Provinsi Jawa Barat
}

\begin{abstract}
Abstrak
Gizi kurang masih menjadi suatu masalah kesehatan terutama di negara-negara berkembang, termasuk Indonesia. Salah satu faktor yang berkaitan dengan kejadian ini adalah kondisi sosioekonomi. Terlepas dari angka kemiskinan yang cenderung menurun dalam beberapa tahun terakhir, masih banyak kasus gizi kurang yang ditemukan terutama pada anak usia 5-12 tahun di Kota Bandung. Penelitian ini bertujuan mengetahui gambaran status sosioekonomi keluarga pada anak usia 5-12 tahun yang mengalami gizi kurang di Kota Bandung. Penelitian ini merupakan penelitian deskriptif dengan desain cross sectional. Subjek penelitian ini yaitu orangtua dan murid usia 5-12 tahun di SD Pertiwi, Kecamatan Bandung Wetan, Kota Bandung. Instrumen yang digunakan dalam penelitian ini berupa form antropometri yang disertai dengan panduan pengukuran bagi orangtua untuk menilai status gizi anak dan kuesioner untuk menilai status sosioekonomi orangtua. Analisis yang digunakan adalah analisis deskriptif univariat untuk menggambarkan karakteristik variabel gizi dan sosioekonomi. Hasil analisis menunjukkan bahwa sebanyak 15,4\% dari 130 murid usia 5-12 tahun di SD Pertiwi Kota Bandung mengalami gizi kurang. Sebesar 72,2\% murid yang mengalami gizi kurang tersebut berasal dari keluarga dengan status sosioekonomi sedang, sedangkan 16,7\% berasal dari keluarga dengan status sosioekonomi rendah. Dari penelitian ini dapat disimpulkan bahwa kejadian gizi kurang pada murid usia 5-12 tahun di SD Pertiwi Kecamatan Bandung Wetan cenderung terjadi pada keluarga dengan status sosioekonomi sedang-rendah.
\end{abstract}

Kata kunci: Anak, gizi kurang, sosioekonomi, usia 5-12 tahun

\section{The Socioeconomic Status of Parents with Undernutritioned Children in Students Aged 5-12 Years at SD Pertivi Bandung Wetan District}

\begin{abstract}
Undernutrition is still a burden in health problem, especially in developing countries, including Indonesia. One factor related to this incident is the socioeconomic conditions. There are still many cases of undernutrition found especially among children aged 5-12 years in Bandung, despite the poverty rate that has tended to decline in the past few years. The goal of this study was to provide an overview of the socioeconomic status of families with undernutritioned children aged 5-12 years in Bandung. This is a descriptive study with cross sectional design. The subjects of this study are parents and students aged 5-12 years at SD Pertiwi, Bandung Wetan District, Bandung City. The instruments used in this study are an anthropometric form accompanied by the measurement guide for parents to assess the nutritional status of children and a questionnaire to assess the socioeconomic status of parents. This study used univariate analysis methods to describe the characteristics of the nutritional and socioeconomic variables. From the analysis, it was found that as many as $15.4 \%$ of 130 students aged 5-12 years at SD Pertiwi, Bandung City, experienced undernutrition. $72.2 \%$ of students experiencing undernutrition come from families with moderate socioeconomic status, while $\mathbf{1 6 . 7 \%}$ come from families with low socioeconomic status. From the study, it can be concluded that undernutrition in children aged 5-12 years in SD Pertiwi, Bandung Wetan District, tends to occur in families with moderate to low socioeconomic status.
\end{abstract}

Keywords: 5-12 years, children, socioeconomy, undernutrition

Received: 8 ...; Revised: ...; Accepted: ...; Published: ...

Koresponden: Fildza Khadijah. Medical Education Study Program, Faculty of Medicine, Bandung Islamic University. Jl. Hariang Banga No. 2, Bandung, West Java. 


\section{Pendahuluan}

Gizi kurang merupakan masalah gizi yang disebabkan oleh pasokan makanan yang tidak adekuat atau ketidakmampuan tubuh untuk melakukan proses metabolisme dan menggunakan unsur-unsur makanan yang diperlukan. ${ }^{1}$ Konsekuensi dari gizi kurang ini, jika tidak segera ditangani, dapat meningkatkan risiko morbiditas dan mortalitas, mempengaruhi proses tumbuh kembang, serta mengganggu perkembangan kognitif dan sosial anak lebih lanjut. ${ }^{2}$

Berdasarkan data pemantauan status gizi nasional tahun 2017 yang dirilis Kementrian Kesehatan Republik Indonesia, tercatat bahwa angka gizi kurang pada anak usia 5-12 tahun mencapai nilai rata-rata 7,5\% dari total 34 provinsi. ${ }^{3}$ Data Profil Kesehatan dari Dinas Kesehatan Provinsi Jawa Barat tahun 2017 menunjukkan bahwa di Kota Bandung kejadian gizi kurang mencapai 11,5\%, melebihi angka ratarata provinsi. 4 Padahal pada usia tersebut anak akan mulai menempuh pendidikan dasar dan memasuki tahap awal pubertas, sehingga membutuhkan asupan gizi yang adekuat untuk menunjang perkembangan fisik dan kognitifnya. Maka dari itu gizi kurang pada anak usia 5-12 tahun di Kota Bandung menjadi suatu masalah kesehatan yang harus dievaluasi dan dicegah. ${ }^{5}$

Penelitian sebelumnya menunjukkan bahwa salah satu faktor risiko penyebab gizi kurang pada anak adalah tingkat sosioekonomi keluarga yang rendah.6_8 Sosioekonomi sendiri merupakan gambaran tentang keadaan dan kedudukan individu dalam suatu masyarakat yang ditinjau dari tingkat pendidikan, pekerjaan, pendapatan dan harta/benda berharga yang dimiliki. Hal ini berkaitan dengan pemasukan dalam keluarga yang turut menentukan ketersediaan dan konsumsi makanan yang dapat mempengaruhi status gizi anggota keluarga tersebut. ${ }^{9}$

Berdasarkan data dari Badan Pusat Statistik (BPS), secara umum terjadi penurunan persentase kemiskinan di Provinsi Jawa Barat pada tahun 20152019, dari 9,57\% menjadi 6,82\%. Hingga pada tahun 2019, jumlah penduduk miskin di Kota Bandung sendiri tercatat sebanyak 84.760 jiwa, atau setara dengan 3,38\% dari keseluruhan jumlah penduduk Kota Bandung. Kondisi perekonomian yang semakin membaik dalam beberapa tahun terakhir ini bertolak belakang dengan kejadian gizi kurang Kota Bandung yang masih tinggi. ${ }^{10 \_12}$

Berdasarkan pemaparan tersebut, peneliti tertarik untuk melakukan kajian untuk mengetahui gambaran status sosioekonomi orangtua murid usia 5-12 tahun yang mengalami gizi kurang di salah satu sekolah dasar yang terdapat di Kecamatan Bandung Wetan, Kota Bandung, yakni SD Pertiwi.

\section{Metode}

Penelitian ini menggunakan metode deskriptif observasional dengan rancangan kuantitatif dan untuk mengetahui gambaran status sosioekonomi orangtua murid usia 5-12 tahun yang mengalami gizi kurang.

Penelitian dilaksanakan di SD Pertiwi, Kecamatan Bandung Wetan, Kota Bandung. Sampel dari penelitian ini adalah murid usia 5-12 tahun sejumlah 130 orang dan orangtua dari murid yang mengalami gizi kurang sejumlah 18 orang. Pengambilan data penelitian terlaksana dengan total waktu 25 hari, sejak tanggal 24 November hingga 23 Desember 2020, dengan prosedur penelitian secara ringkas disajikan dalam bagan berikut

\section{Gambar 1 Alur Penelitian}

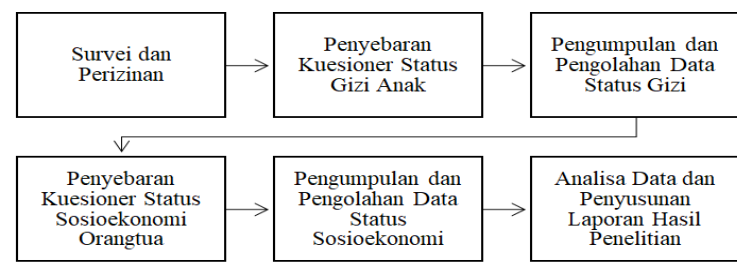

Dalam penelitian ini peneliti hanya menerima kuesioner gizi dan sosioekonomi yang telah diisi oleh orangtua murid. Pengukuran amtropometri dan pengisian kuesioner dilakukan oleh orangtua sesuai instruksi dan panduan yang disediakan peneliti. Prosedur ini telah disetujui oleh Komite Etik Penelitian Kesehatan Fakultas Kedokteran Universitas Islam Bandung nomor 095/KEPK-Unisba/X/2020.

Metode analisis data yang digunakan dalam penelitian ini adalah analisis univariat yang bertujuan untuk menggambarkan karakteristik data dari dua variabel yang diteliti yaitu status gizi murid dan tingkat sosioekonomi orangtua dari murid yang mengalami gizi kurang. Definisi operasional variabel penelitian disajikan dalam tabel berikut

\section{Tabel 1 Definisi Operasional Variabel}

\begin{tabular}{|c|c|c|c|c|}
\hline Variabel & $\begin{array}{l}\text { Alat } \\
\text { Ukur }\end{array}$ & $\begin{array}{c}\text { Definisi } \\
\text { Operasional }\end{array}$ & Hasil Ukur & $\begin{array}{l}\text { Skala } \\
\text { Ukur }\end{array}$ \\
\hline \multirow[t]{2}{*}{$\begin{array}{l}\text { Status Gizi } \\
\text { Anak }\end{array}$} & 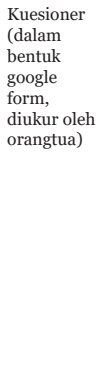 & $\begin{array}{l}\text { Status gizi dinilai dari } \\
\text { hasil plotting indikator } \\
\text { weight for age, height } \\
\text { for age, dan BMI for } \\
\text { age berdasarkan data } \\
\text { usia, berat, tinggi, dan } \\
\text { BMI murid pada tabel } \\
\text { z-score WHO. } \\
\text { (Perhitungan } \\
\text { dilakukan dengan tools } \\
\text { yang disediakan oleh } \\
\text { WHO)13 }\end{array}$ & $\begin{array}{l}\text {-Kategori penilaian } \\
\text {-Gizi Lebih: > } \\
\text { +2 SD } \\
\text {-Normal: -2 hingga } \\
\text { +2 SD } \\
\text {-Gizi Kurang: < } \\
\text {-2 SD } \\
\text {-Dikategorikan } \\
\text { gizi kurang jika } \\
\text { memenuhi kriteria } \\
\text {-Underweight } \\
\text { (BB/U < - - SD) } \\
\text {-Stunted (TB/U < } \\
-2 \text { SD) } \\
\text {-Wasted (IMT } / \mathrm{U}< \\
-2 \text { SD) }\end{array}$ & Ordinal \\
\hline & & $\begin{array}{l}\text { Status sosioekonomi } \\
\text { dinilai berdasarkan } \\
\text { faktor: }\end{array}$ & $\begin{array}{l}\text {-Skor jawaban } \\
\text { A: } 4 \quad \text { C: } 2\end{array}$ & \\
\hline $\begin{array}{l}\text { Status } \\
\text { Sosioekonomi } \\
\text { Orangtua }\end{array}$ & $\begin{array}{l}\begin{array}{l}\text { Kuesioner } \\
\text { (dalam }\end{array} \\
\text { bentuk } \\
\text { google } \\
\text { form, } \\
\text { terdiri atas } \\
25 \text { butir } \\
\text { pertanyaan } \\
\text { pilihan } \\
\text { ganda) }\end{array}$ & 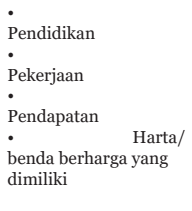 & $\begin{array}{l}\text { B: } 3 \quad \text { D: } 1 \\
\text {-Kategori penilaian } \\
\text {-Tinggi: }>\mathrm{M}+\mathrm{SD} \\
\text {-Sedang: } \mathrm{M}-\mathrm{SD} \leq \\
\mathrm{X}<\mathrm{M}+\mathrm{SD} \\
\text {-Rendah: }<\mathrm{M}-\mathrm{SD} \\
(\mathrm{M}=\text { Mean; } \\
\mathrm{SD}=\mathrm{Standar} \\
\text { Deviasi) }\end{array}$ & Ordinal \\
\hline
\end{tabular}




\section{Hasil}

Berdasarkan hasil analisis data berat badan, tinggi badan, dan BMI terhadap usia pada curva Z-Score WHO dari 130 murid yang memenuhi kriteria inklusi dan tidak termasuk kriteria eksklusi untuk analisis status gizi, didapatkan jumlah dan persentase status gizi sebagai berikut.

Tabel 2 Distribusi Frekuensi Status Gizi

\begin{tabular}{ccc}
\hline Status Gizi Murid & Frekuensi (n) & Persentase (\%) \\
\hline Gizi Lebih & 35 & 26,9 \\
Normal & 75 & 57,7 \\
Gizi Kurang & 20 & 15,4 \\
\hline
\end{tabular}

Berdasarkan tabel 2 di atas dapat diketahui bahwa $15,4 \%$ murid mengalami gizi kurang. Dari total 20 orangtua murid yang mengalami gizi kurang tersebut, 18 orang di antaranya memenuhi kriteria inklusi dan tidak termasuk kriteria eksklusi untuk analisis status sosioekonomi. Berdasarkan hasil analisis data sosioekonomi orangtua murid, didapatkan nilai mean 58,83 dan nilai standar deviasi 7,34 dari total nilai responden, sehingga bisa didapatkan perhitungan nilai interval untuk mengkategorikan status sosioekonomi orangtua murid sebagai berikut.

Tabel 3 Kategori Status Sosioekonomi

\begin{tabular}{|c|c|c|}
\hline Kategori Penilaian & Nilai Interval & $\begin{array}{c}\text { Status } \\
\text { Sosioekonomi }\end{array}$ \\
\hline $\begin{array}{c}>\mathrm{M}+\mathrm{SD} \\
\mathrm{M}-\mathrm{SD} \leq \mathrm{X}<\mathrm{M}+\mathrm{SD} \\
<\mathrm{M}-\mathrm{SD}\end{array}$ & $\begin{array}{c}>66,164 \\
51,496 \leq \mathrm{X}<66,164 \\
<51,496\end{array}$ & $\begin{array}{l}\text { Tinggi } \\
\text { Sedang } \\
\text { Rendah }\end{array}$ \\
\hline \multicolumn{3}{|l|}{ Keterangan } \\
\hline : Standar Dex & & \\
\hline
\end{tabular}

Berdasarkan nilai interval tersebut, maka didapatkan jumlah dan persentase status sosioekonomi orangtua murid sebagai berikut.

Tabel 4 Distribusi Frekuensi Status Sosioekonomi

\begin{tabular}{ccc}
\hline $\begin{array}{c}\text { Status Sosioekonomi } \\
\text { Orangtua }\end{array}$ & Frekuensi (n) & Persentase (\%) \\
\hline Tinggi & 2 & 11,1 \\
Sedang & 13 & 72,2 \\
Rendah & 3 & 16,7 \\
\hline
\end{tabular}

Berdasarkan tabel di atas, dapat diketahui bahwa dari 18 orangtua murid yang mengalami gizi kurang, $72,2 \%$ memiliki status sosioekonomi sedang dan 16,7\% memiliki status sosioekonomi rendah.

\section{Pembahasan}

Berdasarkan hasil penelitian, diperoleh data status gizi murid dan status sosioekonomi orangtua dari murid yang mengalami gizi kurang. Dari hasil analisis status gizi murid didapatkan bahwa sebanyak 57,7\% memiliki status gizi normal, 26,9\% mengalami kondisi gizi lebih dan 15,4\% mengalami kondisi gizi kurang. Sedangkan hasil analisis status sosioekonomi orangtua murid menunjukkan bahwa mayoritas sebesar 72,2\% memiliki status sosioekonomi sedang, disusul dengan status sosioekonomi rendah dan status sosioekonomi tinggi, yang masing-masing berjumlah sebanyak 16,7\% dan $11,1 \%$.

Dari hasil tersebut, dapat dinilai secara tidak langsung bahwa sebagian besar kasus gizi kurang terjadi pada keluarga dengan kondisi sosioekonomi sedang, disusul oleh keluarga dengan sosioekonomi rendah. Hasil ini sejalan dengan teori pada beberapa penelitian yang menyatakan bahwa kondisi gizi kurang cenderung terjadi pada masyarakat atau keluarga dengan status sosioekonomi yang sedang-rendah. 7,14

Status sosioekonomi menggambarkan kemampuan individu atau keluarga dalam memenuhi kebutuhan sehari-hari, hal ini berperan penting dalam mempengaruhi gaya hidup seseorang. 9 Keluarga dengan pendapatan ekonomi yang rendah cenderung lebih memiliki kendala dalam memenuhi kebutuhan nutrisi anaknya, yang mana hal ini berkaitan dengan kemampuan daya beli serta penyediaan makanan dalam rumah tangga. Hal tersebut juga secara langsung berkaitan dengan status gizi anak.

Tingkat pendidikan berpengaruh terhadap tingkat pengetahuan orangtua dan/atau pengasuh akan kesehatan dan kebutuhan gizi yang diperlukan anak. Pemenuhan gizi yang kurang atau tidak seimbang dengan kebutuhan anak dapat menyebabkan tidak maksimalnya tumbuh kembang anak. Selain itu tingkat pendidikan juga dapat mempengaruhi pola asuh yang diberikan orangtua kepada anak. Keluarga dengan tingkat pendidikan yang rendah cenderung tidak memperhatikan pemilihan serta kandungan nilai gizi dalam makanan yang dikonsumsi.7,8

Tingginya kasus gizi kurang yang terjadi pada orangtua dengan status sosioekonomi sedang dibanding status sosioekonomi rendah maupun tinggi dapat diakibatkan karena penduduk dengan status sosioekonomi sedang lebih mendominasi pada populasi yang diteliti secara keseluruhan. Hal ini juga dapat berkaitan dengan pergolakan ekonomi dan penurunan angka kemiskinan di provinsi Jawa Barat yang terjadi dalam beberapa tahun terakhir. ${ }^{10}$

Selain faktor sosioekonomi yang telah diuraikan pada pembahasan sebelumnya; faktor lain seperti genetik, adanya penyakit infeksi, sanitasi dan higiene lingkungan yang buruk, serta pola pemenuhan nutrisi pada masa kehamilan dan awal kehidupan juga berperan dalam mempengaruhi status gizi seseorang.15,16 Beberapa faktor tersebut beserta faktor lainnya yang tidak diteliti dapat meningkatkan risiko terjadinya gizi kurang dan menjadi variabel perancu dalam penelitian ini.

Keterbatasan dalam penelitian ini adalah sedikitnya jumlah sampel serta terbatasnya indikator diagnosis dan instrumen yang digunakan. Selain itu pengukuran dan pengisian kuesioner juga tidak dapat dilakukan maupun dipantau secara langsung oleh peneliti dikarenakan kondisi pandemi yang terjadi.

\section{Simpulan}

Berdasarkan hasil analisis data, dapat disimpulkan bahwa gizi kurang pada murid usia 5-12 tahun di SD Pertiwi Kecamatan Bandung Wetan lebih cenderung terjadi pada keluarga dengan status sosioekonomi sedang-rendah. 


\section{Konflik Kepentingan}

Tim peneliti tidak memiliki konflik kepentingan.

\section{Ucapan Terima Kasih}

Dalam kesempatan ini kami mengucapkan terima kasih kepada Fakultas Kedokteran Universitas Islam Bandung yang telah mendukung dan membantu dalam penulisan penelitian ini.

\section{Daftar Pustaka}

1. Dorland WAN. Dorland's illustrated medical dictionary. Edisi ke-32. Philadelphia: ElsevierSaunders; 2012.

2. Kliegman RM, Stanton BM, st Geme III JW, Schor NF. Nelson textbook of pediatrics. Edisi ke-20. Philadelphia: Elsevier; 2016.

3. Kementrian Kesehatan Republik Indonesia. Pemantauan status gizi tahun 2017. Jakarta: Kementrian Kesehatan Republik Indonesia; 2018

4. Dinas Kesehatan Provinsi Jawa Barat. Profil Kesehatan 2017. Jawa Barat: Dinas Kesehatan Provinsi Jawa Barat; 2018.

5. Kementrian Kesehatan Republik Indonesia. Situasi gizi di Indonesia. Jakarta: Kementrian Kesehatan Republik Indonesia; 2016

6. Who.int [hompage on the Internet]. Malnutrition; c2020 [updated 2020 Apr 1]. Tersedia dari: https://www.who.int/news-room/fact-sheets/ detail/malnutrition

7. Sirasa F, Mitchell FJ, Rigby R, Harris N. Family and community factors shaping the eating behaviour of preschool-aged children in low and middle-income countries: a systematic review of interventions. Prev Medicine. 2019 Aug 30;129(105827):1-13.

8. Almatsier S. Prinsip dasar ilmu gizi. Jakarta: PT.Gramedia Utama; 2002.

9. Soetjiningsih. Tumbuh kembang anak. Jakarta: EGC; 2002

10. Badan Pusat Statistik [database on the Internet] Jakarta: Persentase penduduk miskin menurut provinsi 2007-2020. c2020 [diunduh 20 Desember 2020]. Tersedia dari: https://www.bps. go.id/likTableDinamis/view/id/1219

11. Dinas Kesehatan Kota Bandung. Profil kesehatan Kota Bandung tahun 2018. Bandung: Dinas Kesehatan Kota Bandung; 2019.

12. Dinas Kesehatan Kota Bandung. Profil kesehatan Kota Bandung tahun 2019. Bandung: Dinas Kesehatan Kota Bandung; 2020.

13. World Health Organization. WHO AnthroPlus for personal computers manual: Software for assessing growth of the world's children and adolescents. Geneva: WHO; 2009.

14. Black RE, Victora CG, Walker SP, Bhutta ZA, Christian P, de Onis M, dkk.; Maternal and Child Nutrition Study Group. Maternal and child undernutrition and overweight in low-income and middle-income countries. Lancet. 2013 Aug 3;382(9890):427-51.

15. Asfaw M, Wondaferash M, Taha M, Dube L. Prevalence of undernutrition and associated factors among children aged between six to fifty nine months in Bule Hora district, South Ethiopia. BMC Public Health. 2015 Jan 31;15(41):1-9.

16. Boah M, Azupogo F, Amporfro DA, Abada LA. The epidemiology of undernutrition and its determinants in children under five years in Ghana. Plos One. 2019 Jul 31;14(7):1-23 